
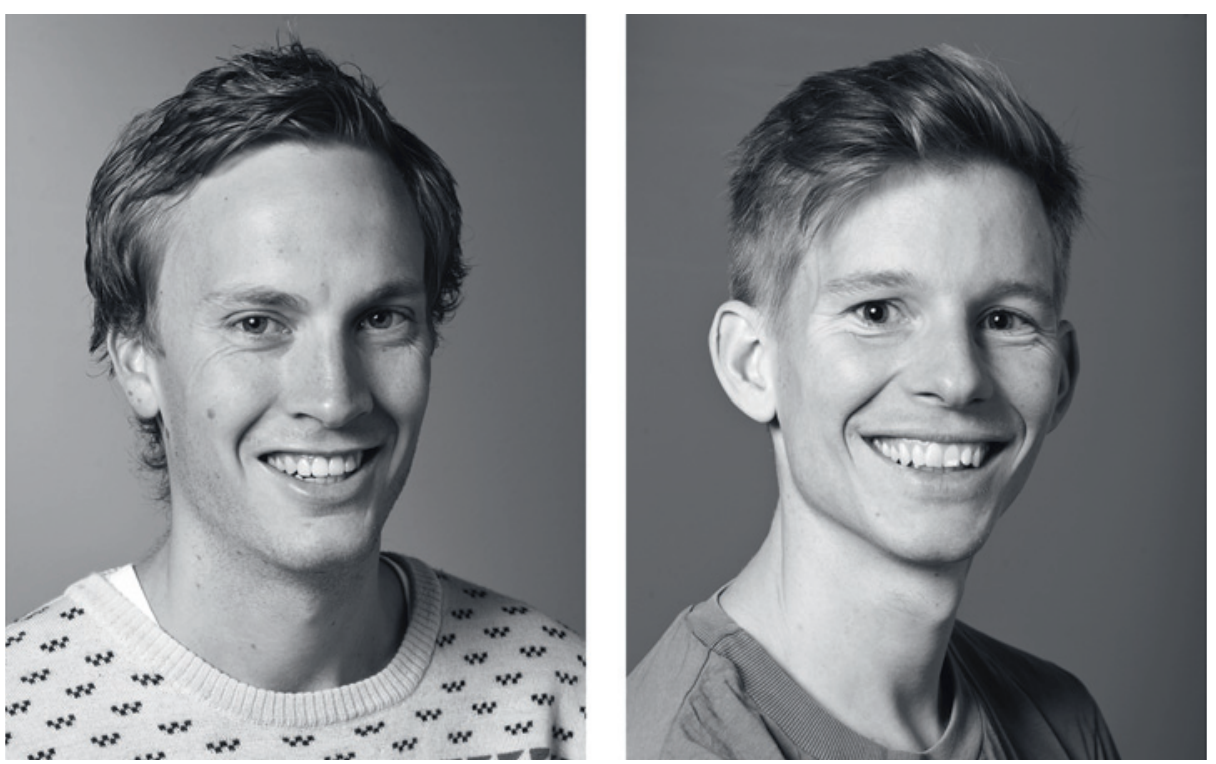

Ordforklaringer

Best interest standard vil si en standard som legene skal følge når de tar sine avgjørelser, som tar sikte på å fremme det som vil være til pasientens beste.

Øystein Therkelsen og Eirik Hagen. Foto Øystein H. Horgmo

\title{
Hvordan er barnelegers holdninger til resuscitering?
}

\author{
Blir nyfødte devaluert ved behov for livreddende intervensjon ved akutt \\ livstruende sykdom? En ny norsk studie kan tyde på det.
}

Studien ble gjennomført ved hjelp av et nettbasert spørreskjema (QuestBack), der alle medlemmer av Barnelegeforeningen som var registrert med en e-postadresse, ble invitert til å delta $(n=676)$, hvorav 266 svarte (39\%) (1). Spørreskjemaet presenterte seks pasienter i ulik alder som alle trengte resuscitering. Alle hadde samme prognose $(50 \%$ overlevelse) og risiko for sekveler (50\%).

De seks pasienthistoriene omfattet to nyfødte (én født i svangerskapsuke $24 \mathrm{og}$ én født til termin), et to måneder gammelt spedbarn, en sjuåring, en 50-åring og en 80 -åring. Barnelegene ble stilt flere spørsmål, bl.a. om de mente at behandling var i pasientens beste interesse, om de ville godta om foreldrene ikke ønsket behandling og om de ville behandlet eget barn.

Rundt tre firedeler av dem som svarte, mente at behandling var til pasientens beste for de fem yngste pasientene, men for de to nyfødte mente signifikant færre at det var til pasientens beste å bli behandlet. $62-72 \%$ ville respektert foreldres ønske om ikke å gi behandling. Dette var signifikant flere enn for de andre pasientene. Respondentene vektla i størst grad risiko for nedsatt livskvalitet og livslengden til de nyfødte som begrunnelse.

- Pasientens beste interesse må ligge til grunn når man bestemmer seg for å behandle eller ikke behandle, sier førsteforfatterne Eirik M. Hagen og Øystein B. Therkelsen.
For barn og nyfødte utøves pasientens autonomi av foreldrene. Studien viser at det kan være vanskelig å vurdere hva som er til nyfødtes beste, hva foreldres preferanser er og hvilke behandlingsvalg legen skal treffe. I studien blir det pekt på problemene med å følge prinsippet om behandling etter en standard for beste interesse, sier Hagen og Therkelsen.

\section{Om forskergruppen}

Artikkelen er basert på en studentoppgave ved Det medisinske fakultet i Oslo. Eirik M. Hagen og Øystein B. Therkelsen, som har delt førsteforfatterskap, avla medisinsk embetseksamen i januar 2012. De øvrige forfatterne er Reidun Førde, professor ved senter for medisinsk etikk, Universitetet i Oslo, Annie Janvier, neonatolog og professor i Montreal, Olaf Gjerløw Aasland, professor ved Institutt for helse og samfunn, Universitetet i Oslo, og hovedveileder Thor Willy Ruud Hansen, professor i pediatri ved Oslo universitetssykehus, Rikshospitalet.

\section{Erlend Hem}

erlend.hem@medisin.uio.no

Tidsskriftet

\section{Litteratur}

1. Hagen EM, Therkelsen $\emptyset \mathrm{B}$, Førde R et al. Challenges in reconciling best interest and parental exercise of autonomy in pediatric life-or-death situations. J Pediatr 2012; e-publisert 22.2.2012.

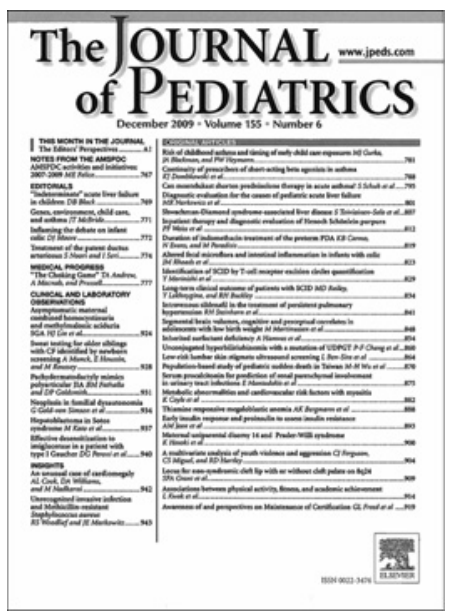

Artikkelen ble e-publisert 22.2. 2012 i det velrenommerte tidsskriftet The Journal of Pediatrics (www.jpeds.com). 